\title{
PERTUMBUHAN TANAMAN MERANTI MERAH (Shorea pauciflora KING) UMUR 36 BULAN DENGAN METODE RUMPANG DI HUTAN PENELITIAN KINTAP, KALIMANTAN SELATAN
}

(Growth of Shorea pauciflora 36 months old with Gap Planting Method in Kintap Research Forest, South Kalimantan)

\author{
Oleh/By: \\ Sudin Panjaitan ${ }^{1}$, Rusmana ${ }^{2}$ dan/and M. Sukma Alamsyah ${ }^{3}$ \\ ${ }^{1}$ Peneliti Madya bidang Silvikultur pada Balai Penelitian Kehutanan Banjarbaru, \\ Kalimantan Selatan \\ ${ }^{2}$ Peneliti Pertama bidang Silvikultur pada Balai Penelitian Kehutanan Banjarbaru, \\ Kalimantan Selatan \\ ${ }^{3}$ Teknisi Litkayasa Pemula bidang Silvikultur pada Balai Penelitian Kehutanan Banjarbaru, \\ Kalimantan Selatan
}

\begin{abstract}
The aimed of this research were : 1) to find out optimal size which give best performance for meranti merah growth on the mahang shrub area, and, 2) to find out the silvicultur technology for meranti merah. The treatments were four level of gap size on meranti merah planting, i.e: 1) without gap planting, 2) $6 m$ diameter, 3) $9 m$ diameter, $12 m$ diameter gap size, replicated six time. Randomized Completed Design was used in this research. The location of this research was Kintap forest research. The result showed diameter gap size of $9 \mathrm{~m}\left(245 \mathrm{~m}^{2}\right.$ wide) and $12 \mathrm{~m}$ (542 $\mathrm{m}^{2}$ wide) significantly affected the growth of meranti merah at 36 month old compared with diameter gap size of $6 \mathrm{~m}\left(113 \mathrm{~m}^{2}\right.$ wide) and control.
\end{abstract}

Key Words : Growth, red meranti, Shorea pauciflora, gap planting.

\begin{abstract}
ABSTRAK
Tujuan penelitian ini adalah untuk : 1) mengetahui ukuran luas rumpang optimal yang memberikan pertumbuhan terbaik jenis meranti merah (Shorea pauciflora) pada areal belukar mahang, dan 2) didapatkannya paket teknologi silvikultur jenis meranti merah (Shorea pauciflora). Perlakuan yang diberikan terdiri 4 taraf ukuran rumpang (gap), yaitu 1) tanpa rumpang $\left(\mathrm{A}_{0}\right), 2$ ) rumpang ukuran diameter $\left.6 \mathrm{~m}\left(\mathrm{~A}_{1}\right), 3\right)$ rumpang ukuran diameter $9 \mathrm{~m}\left(\mathrm{~A}_{2}\right)$, dan 4) rumpang ukuran diameter $12 \mathrm{~m}\left(\mathrm{~A}_{3}\right)$. Diulang sebanyak 6 kali. Penelitian ini didesain menggunakan Rancangan Acak Lengkap. Penelitian ini dilakukan di Hutan Penelitian Kintap. Hasil pengukuran tanaman meranti merah (Shorea pauciflora) umur 36 bulan pada ukuran rumpang diameter $9 \mathrm{~m}$ (luas $=245 \mathrm{~m}^{2}$ ) dan ukuran rumpang diameter $12 \mathrm{~m}$ (luas $=542 \mathrm{~m}^{2}$ ) berpengaruh nyata dan positif terhadap pertumbuhan meranti merah (Shorea pauciflora) dan berbeda sangat nyata dibanding ukuran rumpang diameter $6 \mathrm{~m}$ (luas $=113$ $\mathrm{m}^{2}$ ) dan kontrol.
\end{abstract}

Kata Kunci : Pertumbuhan, meranti merah, Shorea pauciflora, tanaman rumpang. 


\section{PENDAHULUAN}

\section{A. Latar Belakang}

Hutan hujan tropik Indonesia merupakan kekayaan alam yang memegang peranan penting dan dimanfaatkan sebagai penghasil sumber devisa negara serta meningkatkan kesejahteraan masyarakat. Namun di lain pihak akan menimbulkan permasalahan yang diakibatkan oleh pemanfaatan yang berlebihan dan peningkatan penggunaan lahan hutan untuk berbagai penggunaan lainnya sebagai akibat pertumbuhan ekonomi yang sangat pesat. Permasalahan yang terjadi dan memprihatinkan saat ini adalah terjadinya degradasi hutan alam dan tanaman yang mencapai luas 1,6 -2,0 juta hektar/tahun (FAO, 2000). Akibatnya produksi hutan alam drastis menurun, sehingga tidak mampu sebagai pemasok bahan baku industri perkayuan baik ekspor maupun keperluan dalam negeri.

Nicholson (1979) dalam Rahman (1992) mengemukakan bahwa hutan hujan tropik sering pula disebut sebagai hutan Dipterocarpaceae campuran sebab jenis-jenis Dipterocarpaceae secara kolektif dominan di tingkat pohon dan hingga saat ini jenis tersebut tetap memiliki nilai komersial yang tinggi. Selanjutnya Newman, Burgess dan Whitmore (1999) melaporkan bahwa Dipterocarpaceae merupakan suku penghasil kayu yang sangat unggul dari kawasan hutan tropik di Asia.

Kebutuhan bahan baku industri tahun 2000 telah mencapai sekitar 150 juta $\mathrm{m}^{3} /$ tahun, sementara rata-rata produksi hutan alam dan tanaman mencapai 23,9-61,6 juta $\mathrm{m}^{3} /$ tahun. Kesenjangan ini tentu menimbulkan berbagai masalah baru yakni eksploitasi berlebihan, penebangan liar (illegal logging), kebakaran, perambahan, perladangan berpindah dan lain sebagainya. Sebagai akibat dari aktivitas tersebut, maka suatu saat dikhawatirkan akan terjadi kelangkaan suatu jenis yang merupakan andalan unggul yang memiliki nilai ekonomis tinggi dalam dunia perdagangan. Salah satu jenis andalan setempat adalah famili Dipterocarpaceae yang didominasi jenis meranti (Shorea spp.). Diantaranya adalah jenis meranti merah (Shorea pauciflora King) dan Tengkawang (Shorea stenoptera) yang saat ini sedang dikembangkan di Hutan Penelitian Kintap. Selama ini diketahui bahwa jenis-jenis pohon di hutan alam produksi didominasi oleh jenis Dipterocarpaceae yang menjadi unggulan setempat karena jenis ini termasuk kelompok yang memiliki nilai ekonomis tinggi dalam pasaran dunia khususnya komoditi hasil hutan berupa kayu (Martawijaya dkk, 1989). Berdasarkan hasil tinjauan lapangan di beberapa lokasi dan hasil penelitian dari para peneliti/pakar kehutanan, dari beberapa jenis meranti tersebut saat ini terasa sulit ditemukan di beberapa tempat, seperti Shorea pauciflora dan Shorea stenoptera. Upaya-upaya memenuhi kebutuhan bahan baku industri tersebut baik dalam negeri maupun ekspor adalah melalui pembangunan hutan tanaman mengandalkan jenis-jenis prioritas andalan setempat. Pemerintah telah mencanangkan melalui program pembangunan hutan tanaman sejak tahun 1984 dalam rangka meningkatkan produktivitas kawasan hutan produksi untuk tujuan memenuhi bahan baku perkayuan secara berkesinambungan baik dalam negeri maupun ekspor. 
Program ini juga dimaksudkan agar eksploitasi berlebihan terhadap hutan alami dapat diatasi, sehingga kelestarian hutan dan produksi hutan alami dapat dipertahankan. Untuk mencapai tujuan tersebut, maka perlu dilakukan penerapan manajemen yang menjadi suatu keharusan dan juga penerapan silvikultur intensif.

Tujuan utama dari pembangunan hutan tanaman khususnya jenis meranti antara lain adalah : 1) melestarikan jenis meranti (Shorea spp.) yang memiliki nilai komersial dalam dunia perdagangan yang mendominasi kebutuhan bahan baku industri perkayuan nasional, 2) untuk mengatasi kesenjangan antara supply dan demand bahan baku industri utamanya kayu pertukangan, 3) untuk menunjang pembangunan daerah secara berkelanjutan melalui hasil penjualan dari usaha pengelolaan hutan tanaman secara lestari, 4) menyediakan lapangan perkerjaan, dan 5) memfasilitasi penelitian dan pendidikan baik untuk tujuan komersial maupun ilmu pengetahuan.

Panjaitan et al. (2004) melaporkan bahwa penanaman 4 jenis meranti metode rumpang telah dilaksanakan di Hutan Penelitian Kintap pada tahun 1993 dengan ukuran rumpang diameter $10 \mathrm{~m}$ (= luas $78,5 \mathrm{~m}^{2}$ ) dimana setelah tanaman berumur 9 tahun menunjukkan hasil jenis Shorea leprosula, $S$. parvistipulata, S. ovalis dan Shorea pauciflora memiliki riap diameter masing-masing $1,10 \mathrm{~cm} ; 0,97$ $\mathrm{cm} ; 0,97 \mathrm{~cm}$ dan $1,04 \mathrm{~cm}$. Pertumbuhan diameter tertinggi ditunjukkan oleh Shorea leprosula dan diikuti Shorea pauciflora.

Penelitian ini dilakukan untuk mengetahui metode penanaman yang tepat terutama jenis-jenis prioritas andalan setempat, sehingga mampu meningkatkan produktivitas lahan. Hal yang sangat mendasar yang segera harus dikuasai bila akan melakukan kegiatan pengembangan suatu jenis tanaman unggulan setempat pada tapak tertentu ialah pengetahuan sifat silvikultur jenis yang akan dikembangkan, sehingga dengan mudah diketahui dan ditentukan teknik pengembangan budidaya terutama pembangunan tanaman di lapangan agar tercipta kesesuaian jenis dengan tapak yang ada (site-species matching).

Sebagian besar teknik budidaya jenis meranti telah diterapkan seperti teknik pengadaan bibit di persemaian, teknik penanaman dan teknik pemeliharaan. Namun demikian untuk beberapa jenis, penguasaan dari aspek silvikultur belum diketahui secara menyeluruh.

Hipotesis dari penelitian ini adalah ukuran rumpang memberikan pengaruh terhadap pertumbuhan tanaman meranti merah (Shorea pauciflora).

\section{B. Tujuan Penelitian}

Penelitian ini bertujuan untuk : 1) mengetahui luas rumpang optimal yang memberikan pertumbuhan tanaman terbaik jenis meranti merah (Shorea pauciflora) pada areal belukar mahang, dan 2) didapatkannya paket teknologi silvikultur dalam rangka pengembangan Shorea pauciflora skala luas. Sedangkan sasaran yang ingin dicapai dari penelitian ini adalah tersedianya data dan 
informasi teknik pembuatan tanaman yang cocok, sehingga dapat meningkatkan pertumbuhan tanaman meranti merah (Shorea pauciflora) pada vegetasi belukar mahang.

\section{BAHAN DAN METODE PENELITIAN}

\section{A. Lokasi Penelitian}

Penelitian ini dilaksanakan di Hutan Penelitian Kintap pada vegetasi belukar mahang. Lokasi ini merupakan Eks HPH PT. Hutan Kintap. Menurut data administrasi pemerintah daerah, lokasi ini termasuk dalam Desa Riam Adungan, Kecamatan Kintap, Kabupaten Daerah Tingkat II Tanah Laut, Provinsi Kalimantan Selatan. Secara geografis, lokasi terletak pada $3^{\circ} 42^{\prime}$ Lintang Selatan dan $115^{\circ} 9^{\prime}$ Bujur Timur. Jarak dari ibu kota Banjarmasin $150 \mathrm{~km}$ arah Tenggara. Ketinggian tempat 50-150 m dpl. Tanah di areal Hutan Penelitian Kintap termasuk ordo ultisols, beberapa bagian terdapat tanah berlumpur (gley) dan ultisols, partikel tanah didominasi oleh fraksi liat dengan pH 4,8-6,1 dengan fosfor, karbon organik, kapasitas tukar kation yang relatif tinggi (Jafarsidik, 1998). Menurut tipe curah hujan Schmidt dan Ferguson (1951), iklim di lokasi penelitian termasuk tipe iklim B dengan curah hujan rata-rata tahunan sebesar $3.017 \mathrm{~mm} /$ tahun dan hari hujan rata-rata tahunan sebesar 154 hari/tahun.

\section{B. Bahan dan Peralatan}

Bahan yang digunakan sebagai obyek pada penelitian ini adalah tanaman meranti merah (Shorea pauciflora) umur 36 bulan ditanam Desember 2004 dan diukur Desember 2007. Sedangkan peralatan utama yang digunakan adalah : 1) Kompas untuk menentukan arah rintis plot, 2) Parang untuk membuat rintisan/jalan pemeriksaan plot, 3) Meteran untuk mengukur tinggi pohon, 4) Altimeter untuk mengukur ketinggian tempat, 5) Soil tester (pengukur $\mathrm{pH}$ tanah), 6) Luxmeter untuk mengukur intensitas cahaya, 7) Jangka sorong (kaliper) untuk mengukur diameter batang, 8) Cat dan kuas untuk penandaan plot, ajir tanam dan batas plot, 9) Bor tanah dan ring tanah untuk mengambil sampel tanah, 10) Kamera untuk dokumentasi, 11) Tally sheet/tabel pengamatan untuk merekam data pengamatan, dan 12) Peralatan pendukung lainnya.

\section{Rancangan Penelitian}

\section{Perlakuan yang diberikan}

Penelitian ini menggunakan ukuran rumpang sebagai perlakuan. Perlakuan yang diberikan berupa ukuran rumpang yang berbeda-beda yang terdiri dari 4 taraf yaitu :

1) Tanpa rumpang/kontrol (di bawah naungan)

2) Rumpang ukuran diameter $6 \mathrm{~m}$ (luas $\left.=113 \mathrm{~m}^{2}\right) \quad(\mathrm{r}=3 \mathrm{~m})$

3) Rumpang ukuran diameter $9 \mathrm{~m}$ (luas $\left.=245 \mathrm{~m}^{2}\right)(\mathrm{r}=4,5 \mathrm{~m})$

4) Rumpang ukuran diameter $12 \mathrm{~m}$ (luas $\left.=542 \mathrm{~m}^{2}\right)(\mathrm{r}=6 \mathrm{~m})$ 
Rancangan yang digunakan pada penelitian ini adalah Rancangan Acak Lengkap dengan 4 perlakuan dan diulang sebanyak 6 kali (Sudjana, 1991). Jarak antar rumpang $10 \mathrm{~m}$ dan jarak tanam dalam rumpang $2 \times 2 \mathrm{~m}$. Jumlah rumpang keseluruhan sebanyak $4 \times 6=24$ unit rumpang (satuan percobaan). Setiap unit perlakuan terdiri dari 5-21 tanaman dan ditunjuk 5 tanaman sebagai sampel pengamatan. Pemeliharaan tanaman yang dilakukan meliputi pembersihan gulma pengganggu di setiap unit perlakuan ukuran rumpang tanam dengan cara tebas total pada unit rumpang tersebut. Pengendalian gulma cara tebas dilakukan setiap 3 (tiga) bulan sekali.

\section{Parameter}

Parameter yang diukur adalah :

1) Tinggi tanaman (cm),

2) Diameter batang $(\mathrm{cm})$,

3) Daya hidup (\%), dan

4) Lebar tajuk dan tinggi tajuk (cm).

\section{Pengambilan data}

Pendataan dilakukan terhadap respon pertumbuhan tanaman meranti merah (Shorea pauciflora) yang ditanam pada beberapa ukuran luas rumpang (sebagai perlakuan).

\section{Analisis data}

Setelah data dikumpulkan kemudian dilakukan analisis data dengan menggunakan Anova. Apabila terdapat perbedaan yang nyata dilakukan uji lanjutan menggunakan uji Duncan.

\section{HASIL DAN PEMBAHASAN}

\section{A. Pertumbuhan Tanaman Meranti Merah (Shorea pauciflora)}

\section{Tinggi tanaman $(\mathrm{cm})$}
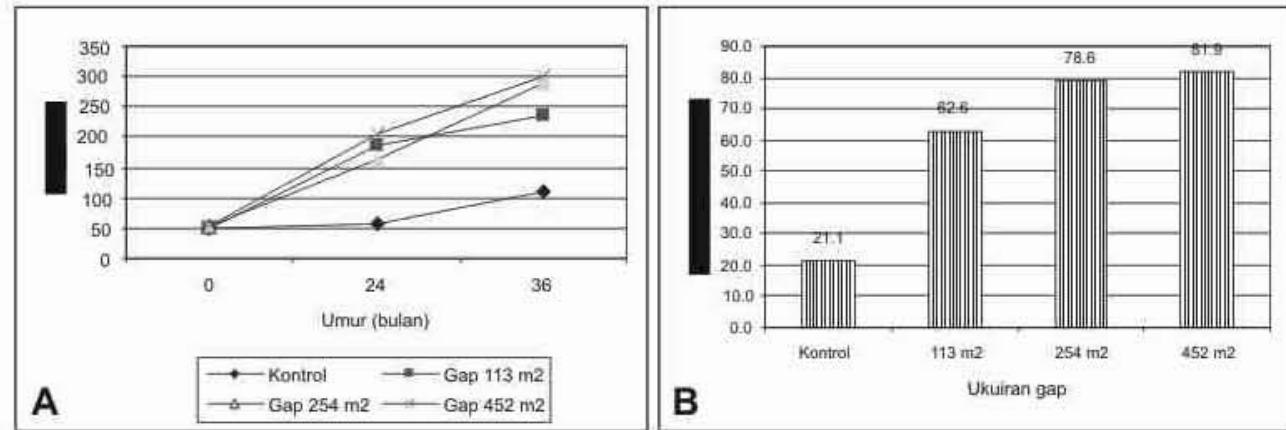

Gambar (Picture) 1. Pertumbuhan tinggi tanaman meranti merah pada umur 0, 24 dan 36 bulan (A) dan rata-rata riap tinggi per tahun sampai umur 36 bulan pada 4 perlakuan ukuran rumpang (B) di Hutan Penelitian Kintap (The growth of meranti merah 0;24 months and 36 months and the average of growth hight until those ages on 4 treatment of the size of rumpang at the recherche forest). 
Kecenderungan pertumbuhan tanaman meranti merah umur 36 bulan seperti disajikan pada Gambar 1. Pertumbuhan rata-rata tinggi tanaman pada kontrol, ukuran rumpang $113 \mathrm{~m}^{2}, 254 \mathrm{~m}^{2}$ dan $452 \mathrm{~m}^{2}$ berturut-turut adalah $111,3 \mathrm{~cm} ; 237,3 \mathrm{~cm} ; 290,6 \mathrm{~cm}$ dan $300,5 \mathrm{~cm}$.

Pada Tabel 1 dan 2 ditunjukkan bahwa ukuran gap yang memberikan respon terbaik terhadap pertumbuhan tinggi tanaman adalah ukuran gap $254 \mathrm{~m}^{2}$ dan $452 \mathrm{~m}^{2}$ dengan rata-rata tinggi tanaman berturut-turut adalah $290,6 \mathrm{~cm}$ dan $300,5 \mathrm{~cm}$. Sementara pada ukuran gap $113 \mathrm{~m}^{2}$ dan kontrol tingginya $237,3 \mathrm{~cm}$ dan $111,3 \mathrm{~cm}$. Pertumbuhan tinggi tanaman meranti merah pada umur 36 bulan ( 3 tahun) pada perlakuan ukuran gap $254 \mathrm{~m}^{2}$ dan $452 \mathrm{~m}^{2}$ menunjukkan perbedaan yang sangat nyata dibanding ukuran gap $113 \mathrm{~m}^{2}$ dan tanpa rumpang/kontrol $(\mathrm{P}=0,000<0,01)$. Dengan demikian ukuran gap pada luasan $254 \mathrm{~m}^{2}$ dan $452 \mathrm{~m}^{2}$ untuk pengembangan penanaman meranti merah pada lahan belukar tua atau bekas tebangan dapat dilakukan karena pertumbuhan tanamannya lebih baik dibanding pada ukuran rumpang yang lebih sempit.

Tabel (Table) 1. Analisis sidik ragam tinggi tanaman meranti merah pada umur 36 bulan (The analys of variance of meranti merah's heigh at 36 months age).

\begin{tabular}{|l|r|r|r|r|l|}
\hline $\begin{array}{c}\text { Sumber Keragaman } \\
\text { (SK) }\end{array}$ & \multicolumn{1}{c|}{$\begin{array}{c}\text { Jumlah } \\
\text { Kuadrat (JK) }\end{array}$} & \multicolumn{1}{c|}{ db } & $\begin{array}{r}\text { Kuadrat Tengah } \\
\text { (KT) }\end{array}$ & \multicolumn{1}{c|}{ F hit } & \multicolumn{1}{c|}{ Sig./P } \\
\hline Ukuran gap & 228948.578 & 3 & 76316.193 & 11.353 & $.000 * *$ \\
Blok & 251058.972 & 5 & 50211.794 & 7.470 & .000 \\
Error & 470554.885 & 70 & 6722.213 & & \\
Total & 6439414.000 & 79 & & & \\
\hline
\end{tabular}

Keterangan : ** = berbeda sangat nyata $(\mathrm{P}=0,000<0,01)$

Tabel (Table) 2. Uji lanjut Duncan tinggi tanaman meranti merah pada umur 36 bulan The duncan treatment of meranti merah's heigh at 36 months age

\begin{tabular}{|l|c|c|c|c|}
\hline \multirow{2}{*}{ Ukuran gap } & \multirow{2}{*}{$\mathrm{N}$} & \multicolumn{3}{c|}{ Subset } \\
\cline { 3 - 5 } & & 1 & 2 & 3 \\
\hline Kontrol (Ao) & 12 & 113.7500 & & \\
\hline $113 \mathrm{~m}^{2}$ (A1) & 14 & & 242.7857 & \\
\hline $254 \mathrm{~m}^{2}$ (A2) & 25 & & 290.6000 & 290.6000 \\
\hline $452 \mathrm{~m}^{2}$ (A3) & 28 & & & 306.2500 \\
\hline
\end{tabular}

\section{Diameter batang $(\mathrm{cm})$}

Kecenderungan pertumbuhan diameter batang ( $10 \mathrm{~cm}$ dari permukaan tanah) mulai umur 0,24 dan 36 bulan (A) dari masing-masing perlakuan menunjukkan pertumbuhan yang bervariasi. Diameter batang pada umur 36 bulan ( 3 tahun) pada masing-masing perlakuan tanpa rumpang dan luas gap 113 $\mathrm{m}^{2}, 254 \mathrm{~m}^{2}$ dan $452 \mathrm{~m}^{2}$ berturut-turut adalah $8,5 \mathrm{~mm} ; 18,7 \mathrm{~mm} ; 26,4 \mathrm{~mm}$ dan $26,4 \mathrm{~mm}$. Sedangkan riap diameter per tahun dari masing-masing perlakuan tersebut adalah 7,6 mm;19,1 mm;25,3 mm dan $25,3 \mathrm{~mm}$. Diameter batang paling besar ditunjukkan oleh ukuran gap $254 \mathrm{~m}^{2}$ dan $452 \mathrm{~m}^{2}$.

Hasil analisis data terhadap diameter batang disajika pada Tabel 3 dan Tabel 4. 


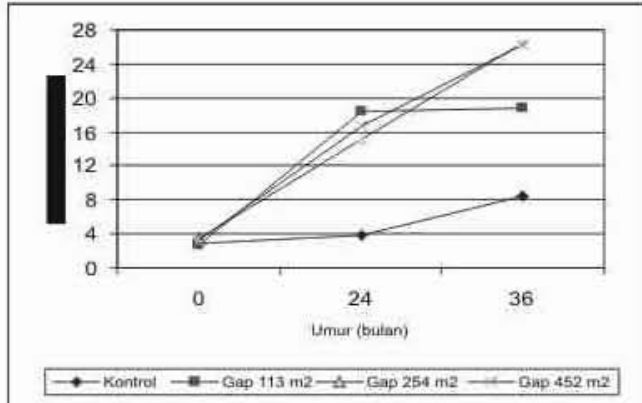

A

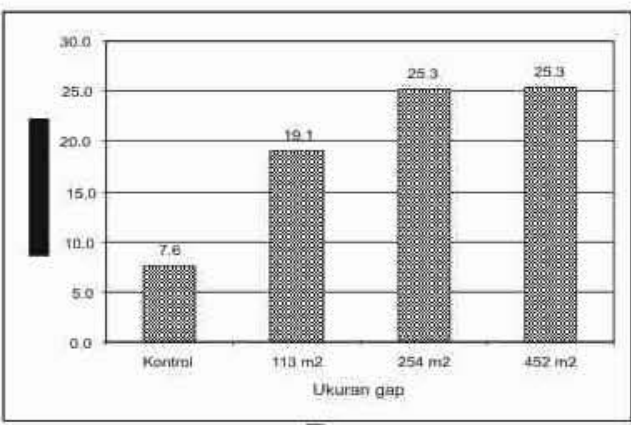

B

Gambar (Picture) 2. Pertumbuhan diameter batang tanaman meranti merah pada umur 0;24 dan 36 bulan (A) dan rata-rata riap diameter per tahun sampai umur 36 bulan pada 4 perlakuan ukuran gap (B) di Hutan Penelitian Kintap (The growth of meranti merah's diametre on 0;24 months age and 36 months age $(A)$ and the average annual of the diameter growth until 36 months on 4 treatment of the size of gap (B) at the Kintap forest research)

Tabel (Table) 3. Analisis sidik ragam diameter batang tanaman meranti merah pada umur 36 bulan (The analys of variance of meranti merah's diameter on 36 months).

\begin{tabular}{|l|r|r|r|r|r|}
\hline $\begin{array}{c}\text { Sumber Keragaman } \\
\text { (SK) }\end{array}$ & \multicolumn{1}{c|}{$\begin{array}{c}\text { Jumlah } \\
\text { Kuadrat (JK) }\end{array}$} & \multicolumn{1}{c|}{$\mathrm{db}$} & $\begin{array}{r}\text { Kuadrat Tengah } \\
\text { (KT) }\end{array}$ & \multicolumn{1}{c|}{ F hit } & Sig./P \\
\hline Ukuran gap & 2256.109 & 3 & 752.036 & 18.398 & $.000 * *$ \\
Blok & 1059.670 & 5 & 211.934 & 5.185 & .000 \\
Error & 2861.345 & 70 & 40.876 & & \\
Total & 47102.360 & 79 & & & \\
\hline
\end{tabular}

Keterangan : ** = berbeda sangat nyata $(\mathrm{P}=0,000<0,01)$

Tabel (Table) 4. Uji lanjut Duncan diameter batang tanaman meranti merah pada umur 36 bulan (The duncan treatment of meranti merah's diametre on 36 months).

\begin{tabular}{|l|c|c|c|c|}
\hline \multirow{2}{*}{ Perlakuan } & \multirow{2}{*}{$\mathrm{N}$} & \multicolumn{3}{|c|}{ Subset } \\
\cline { 3 - 5 } & & 1 & 2 & 3 \\
\hline Kontrol (Ao) & 12 & 8.6667 & & \\
\hline $113 \mathrm{~m}^{2}(\mathrm{~A} 1)$ & 14 & & 18.7000 & \\
\hline $254 \mathrm{~m}^{2}(\mathrm{~A} 2)$ & 25 & & & 26.4440 \\
\hline $452 \mathrm{~m}^{2}(\mathrm{~A} 3)$ & 28 & & & 26.6607 \\
\hline
\end{tabular}

Berdasarkan hasil uji Duncan (Tabel 4), luas rumpang $254 \mathrm{~m}^{2}$ dan luas rumpang $452 \mathrm{~m}^{2}$ dibanding dengan kontrol dan rumpang $113 \mathrm{~m}^{2}$ menunjukkan diameter batang yang berbeda sangat nyata $(\mathrm{P}=$ $0,000<0,01)$. Dengan demikian ukuran rumpang $254 \mathrm{~m}^{2}-452 \mathrm{~m}^{2}$ merupakan ukuran rumpang yang paling sesuai untuk kegiatan penanaman meranti merah di lahan belukar atau di areal bekas tebangan dibanding ukuran rumpang lainnya dan kontrol.

Whitmore (1975) mengemukakan bahwa terdapat 3 fase perkembangan vegetasi yaitu : 1) fase rumpang (pada saat terjadinya rumpang), 2) fase pertumbuhan (proses pertumbuhan dan perkembangan vegetasi yang menempati rumpang), dan 3) fase tua (vegetasi mencapai klimaks dan kemungkinan mendekati asalnya dan strukturnya berlapis) yang setiap saat dapat terjadi rumpang baru. Fase satu 
dengan fase lainnya saling mempengaruhi, berkesinambungan dan merupakan suatu proses dinamis yang disebut small eco-unit.

Sagala (1994) melaporkan bahwa pertumbuhan permudaan alam meranti pada umumnya tumbuh baik pada rumpang (gap) sebab berapa pada iklim mikro rumpang. Oleh karena itu penanaman meranti di areal bekas tebangan atau log over area $(\mathrm{LoA})$ dan di belukar tua dapat digunakan metode rumpang artinya tanaman tembus ke langit, sehingga sinar matahari dapat masuk ke lantai hutan dimana hal ini sangat diperlukan tanaman untuk proses fotosintesis. Dengan metode rumpang, kondisi iklim mikro dalam rumpang cocok untuk pertumbuhan tanaman meranti.

\section{Daya hidup (\%)}

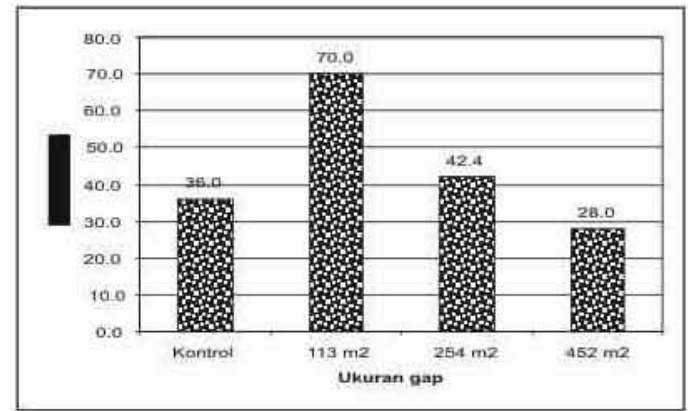

Gambar (Picture) 3. Daya hidup tanaman meranti merah pada umur 36 bulan pada 4 perlakuan ukuran rumpang (The viability of meranti merah at 36 monts age at 4 treatments of gap size).

Daya hidup tanaman terbaik terdapat pada ukuran gap $113 \mathrm{~m}^{2}$ (70\%) dibanding ukuran rumpang lainnya. Kematian tanaman terjadi bukan karena dari perlakuan ukuran gap, tetapi disebabkan oleh gangguan penyaradan kayu oleh kerbau yang dilakukan masyarakat penebang kayu. Selain itu banyak plot penelitian dalam gap rusak dan mati tertimbun tajuk pohon yang ditebang.

\section{Lebar dan tinggi tajuk}
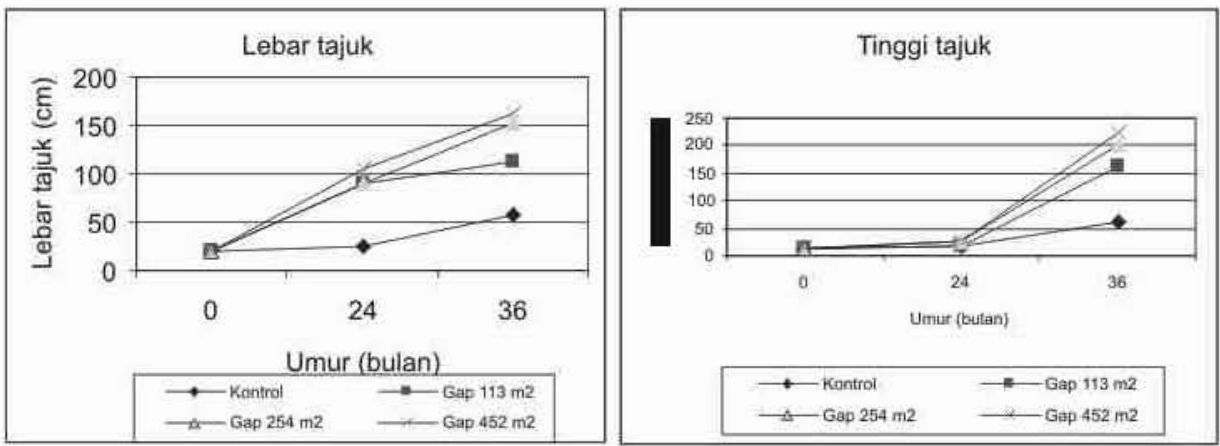

Gambar (Picture) 4. Lebar dan tinggi tajuk tanaman meranti merah pada umur 36 bulan pada 4 perlakuan ukuran rumpang (The width and height of the tree's canopy of meranti merah at 36 monts age at 4 treatments of gap size). 
Pertumbuhan tajuk mulai umur $0 ; 24$ dan 36 bulan menunjukkan ada perkembangan yang bervariasi (Gambar 4). Lebar dan tinggi tajuk cenderung lebih besar (baik) sesuai luas ukuran gap. Artinya, lebih luas gap tajuk tanaman lebih lebar dan lebih tinggi (lebat). Dengan tajuk yang lebat akan terjadi proses fotosintesis lebih besar. Analisis sidik ragam terhadap lebar tajuk tanaman seperti ditampilkan pada Tabel 5 dan Tabel 6. Sedangkan tinggi tajuk dapat dilihat pada Tabel 7 dan Tabel 8.

Tabel (Table) 5. Analisis sidik ragam lebar tajuk tanaman meranti merah pada umur 36 bulan (The analyse of variance of the canopy's wide of meranti merah at 36 monts age).

\begin{tabular}{|l|r|r|r|r|l|}
\hline \multicolumn{1}{|c|}{ Sumber keragaman } & Jumlah kuadrat & db & Kuadrat tengah & \multicolumn{1}{c|}{ F hit } & \multicolumn{1}{|c|}{ Sig./P } \\
\hline Ukuran rumpang & 74164.504 & 3 & 24721.501 & 12.598 & $.000^{* *}$ \\
Blok & 37854.605 & 5 & 7570.921 & 3.858 & .004 \\
Error & 137358.061 & 70 & 1962.258 & & \\
Total & 1754071.750 & 79 & & & \\
\hline
\end{tabular}

Tabel (Table) 6. Uji lanjut Duncan lebar tajuk tanaman meranti merah pada umur 36 bulan (The duncan treatment of the meranti merah's wide at 36 months age).

\begin{tabular}{|l|c|c|c|c|}
\hline \multirow{2}{*}{ Perlakuan } & \multirow{2}{*}{$\mathrm{N}$} & \multicolumn{3}{|c|}{ Subset } \\
\cline { 3 - 5 } & & $\mathrm{I}$ & 2 & 3 \\
\hline Kontrol (Ao) & 12 & 58.8333 & & \\
\hline $113 \mathrm{~m}^{2}(\mathrm{~A} 1)$ & 14 & & 117.0357 & \\
\hline $254 \mathrm{~m}^{2}(\mathrm{~A} 2)$ & 25 & & & 153.5600 \\
\hline $452 \mathrm{~m}^{2}(\mathrm{~A} 3)$ & 28 & & & 164.3214 \\
\hline
\end{tabular}

Hasil analisis terhadap parameter lebar tajuk menunjukkan bahwa ukuran gap $254 \mathrm{~m}^{2}$ dan $452 \mathrm{~m}^{2}$ memiliki rata-rata lebar tajuk yang besar yaitu berturut-turut $153,6 \mathrm{~cm}$ dan $164,3 \mathrm{~cm}$ serta berbeda sangat nyata dengan ukuran gap $113 \mathrm{~m}^{2}$ dan kontrol dengan lebar tajuk tanaman masing-masing 117,0 $\mathrm{cm}$ dan $58,8 \mathrm{~cm}(\mathrm{P}=0,000<0,01)$

Sedangkan hasil analisis terhadap tinggi tajuk menunjukkan bahwa perlakuan kontrol, gap 113 $\mathrm{m}^{2}, 254 \mathrm{~m}^{2}$ dan $452 \mathrm{~m}^{2}$ merespon tanaman dengan tinggi tajuk masing-masing $62,1 \mathrm{~cm} ; 164,5 \mathrm{~cm}$; $202,2 \mathrm{~cm}$ dan $229,0 \mathrm{~cm}$. Berdasarkan uji lanjutan Duncan ukuran gap $254 \mathrm{~m}^{2}$ dan $452 \mathrm{~m}^{2}$ menunjukkan pertumbuhan tinggi tajuk tanaman terbaik dan berbeda sangat nyata dibanding pertumbuhan tinggi tajuk pada ukuran gap $113 \mathrm{~m}^{2}$ dan kontrol $(\mathrm{P}=0,000<0,01)$.

Tabel (Table) 7. Analisis sidik ragam Tinggi tajuk tanaman meranti merah pada umur 36 bulan (The analyse of variance of the meranti merah's canopy at 36 months age).

\begin{tabular}{|l|r|r|r|r|l|}
\hline $\begin{array}{c}\text { Sumber Keragaman } \\
\text { (SK) }\end{array}$ & $\begin{array}{c}\text { Jumlah } \\
\text { Kuadrat }(\mathrm{JK})\end{array}$ & $\begin{array}{c}\text { Derajat } \\
\text { bebas } \\
\text { (db) }\end{array}$ & $\begin{array}{r}\text { Kuadrat Tengah } \\
\text { (KT) }\end{array}$ & F hit & Sig./P \\
\hline Ukuran gap & 163261.343 & 3 & & 8.390 & $.000^{* *}$ \\
Blok & 191594.111 & 5 & 38318.822 & 5.907 & .000 \\
Error & 454067.830 & 70 & 6486.683 & & \\
Total & 3562089.000 & 79 & & \\
\hline
\end{tabular}

Keterangan : $* *=$ berbeda sangat nyata $(\mathrm{P}=0,000<0,01)$ 
Tabel (Table ) 8. Uji lanjut Duncan tinggi tajuk tanaman meranti merah pada umur 36 bulan (The Duncan treatment of height of meranti merah's canopy at 36 months age).

\begin{tabular}{|l|c|c|c|c|}
\hline \multirow{2}{*}{ Perlakuan } & \multirow{2}{*}{$\mathrm{N}$} & \multicolumn{3}{c|}{ Subset } \\
\cline { 3 - 5 } & & 1 & 2 & 3 \\
\hline Kontrol (Ao) & 12 & 62.0833 & & \\
\hline $113 \mathrm{~m}^{2}$ (A1) & 14 & & 164.5000 & 202.2400 \\
\hline $254 \mathrm{~m}^{2}(\mathrm{~A} 2)$ & 25 & & 202.2400 & 229.0357 \\
\hline $452 \mathrm{~m}^{2}(\mathrm{~A} 3)$ & 28 & & & \\
\hline
\end{tabular}

Ruang tumbuh berupa gap pada lahan belukar yang tua atau areal bekas tebangan cocok untuk pertumbuhan tajuk tanaman Meranti. Hal tersebut disebabkan jenis meranti pada umumnya jenis yang tidak menghendaki sinar penuh sepanjang hari tetapi menghendaki sinar yang periodik dan perlu pohon pendamping sebagai naungan untuk menjaga temperatur dan kelembaban tanah.

Berdasarkan pengamatan kondisi iklim mikro gap siang hari (pukul 11.00 - 16.00) pada ukuran gap $452 \mathrm{~m}^{2}$ dan $254 \mathrm{~m}^{2}$ memiliki intensitas cahaya berturut-turut adalah $4.200-21.500$ lux dan 1.500 - 13.000 lux. Pada ukuran gap $113 \mathrm{~m}^{2}$ intensitas cahayanya sebesar 820 - 13.000 lux dan pada kontrol sebesar 100 - 570 lux.

Kelembaban udara pada ukuran gap $452 \mathrm{~m}^{2}, 254 \mathrm{~m}^{2}, 113 \mathrm{~m}^{2}$ dan kontrol berturut-turut adalah $82 \%-84 \%, 82 \%-84 \%, 83 \%-84 \%$ dan $83 \%$ - $85 \%$. Sedangkan temperatur udara terukur siang hari pada masing-masing ukuran gap tersebut rata-rata antara $30^{\circ}-34^{\circ} \mathrm{C}$ kecuali pada perlakuan kontrol yaitu $30^{\circ}-32^{\circ} \mathrm{C}$.

Kondisi iklim mikro tersebut memang berbeda dengan kondisi iklim mikro pada lahan bervegetasi alang-alang. Intensitas cahaya pada vegetasi alang-alang cukup besar ( $>40.000$ lux $)$ yang akan berpengaruh langsung atau tidak langsung terhadap temperatur dan kelembapan udara pada permukaan tanah.

Panjaitan et al. (2004) mengemukakan bahwa penanaman 4 jenis meranti metode rumpang telah dilaksanakan di Hutan Penelitian Kintap pada tahun 1993 dengan ukuran rumpang diameter $10 \mathrm{~m}$ (= luas $78,5 \mathrm{~m}^{2}$ ) dimana setelah tanaman berumur 9 tahun menunjukkan hasil jenis Shorea leprosula, Shorea parvistipulata, Shorea ovalis dan Shorea johorensis memiliki riap diameter masing-masing $1,10 \mathrm{~cm} ; 0,97 \mathrm{~cm} ; 0,97 \mathrm{~cm}$ dan $1,04 \mathrm{~cm}$. Pertumbuhan diameter tertinggi ditunjukkan oleh Shorea leprosula dan diikuti Shorea johorensis.

Sagala (1989) mengemukakan bahwa tanaman tumbuh optimal sangat tergantung dari faktor tempat tumbuh yang memiliki unsur cukup banyak dimana antara satu dengan lainnya saling mempengaruhi. Selanjutnya dikatakan bahwa secara praktis di lapangan, faktor tempat tumbuh dapat dibagi kedalam tiga kelompok. Pertama, faktor tempat tumbuh yang berada di atas tanah yaitu : 1) pohon naungan atas, 2) pohon naungan samping, 3) ukuran rumpang, 4) intensitas cahaya, 5) lamanya penyinaran, 6) temperatur udara, dan 7) kelembaban udara. Kedua, faktor tempat tumbuh yang berada di permukaan tanah, yaitu : 1) jenis gulma, 2) kerapatan gulma, 3) serasah, 4) kelerengan, 5) mikro 
organisme, dan 6) binatang. Ketiga, faktor tempat tumbuh yang berada di dalam tanah yaitu : 1) ketebalan tanah, 2) kegemburan tanah, 3) kandungan unsur hara, 4) $\mathrm{pH}$ tanah, 5) bahan organik, 6) mikoriza, 7) suhu tanah, 8) jenis tanah, dan 9) rhizobium.

Setyati (1984) mengemukakan bahwa faktor lingkungan yang sangat menentukan dan mempengaruhi pertumbuhan tanaman yang dibudidayakan yaitu : 1) tanah yang menyediakan hara dan kelembaban disamping sebagai pendukung secara mekanik, 2) energi penyinaran baik berbentuk panas maupun cahaya, dan 3) udara, yang memberikan karbon dioksida dan oksigen. Selanjutnya dikemukakan bahwa tanah dan energi penyinaran sangat bervariasi di permukaan bumi. Meskipun komposisi udara di atas bumi hampir seragam di atas tanah, besarnya persentase udara di dalam tanah bervariasi sangat besar.

Salah satu langkah penting yang ditempuh dalam rangka pembangunan hutan tanaman adalah pengembangan jenis-jenis pohon andalan setempat (indigenous tree species), sebab telah sesuai dengan habitat aslinya artinya sesuai iklim mikro setempat. Untuk itu penguasaan silvikultur jenis tersebut perlu terus ditingkatkan yang dimulai dari penyediaan bibit di persemaian, teknik persiapan lahan dan teknik penanaman serta teknik pemeliharaan tanaman.

Dari data iklim mikro tersebut, tampak bahwa yang paling penting adalah intensitas cahaya yang masuk dalam rumpang (gap). Dengan intensitas cahaya 4.500 - 21.500 lux, pertumbuhan meranti cukup baik. Penampilan meranti merah pada salah satu ukuran gap ditampilkan pada Gambar 5.
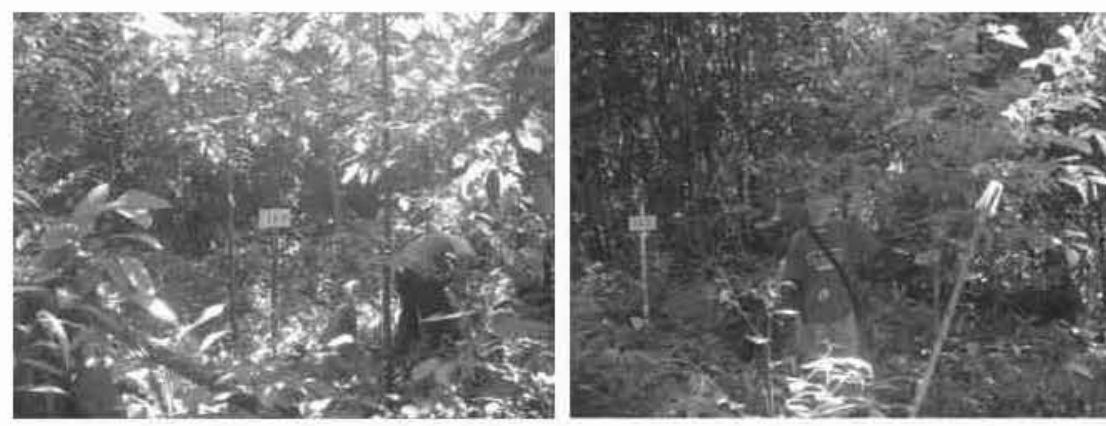

Gambar (Picture) 5. Penampilan tanaman meranti merah umur 36 bulan yang ditanam dengan metode rumpang (gap) (The figure of meranti merah at 36 months age that has been planted with the rumpang method).

\section{KESIMPULAN DAN SARAN}

1. Luas rumpang optimal untuk penanaman meranti merah (Shorea pauciflora) adalah ukuran luas rumpang $254 \mathrm{~m}^{2}$ (rumpang ukuran $\varnothing=9 \mathrm{~m}$ ) dan $452 \mathrm{~m}^{2}$ (rumpang ukuran $\varnothing=12 \mathrm{~m}$ ) pada lahan belukar tua/areal bekas tebangan di Hutan Penelitian Kintap. Hal tersebut ditunjukkan oleh pertumbuhan tinggi, diameter batang, tinggi dan lebar tajuk tanaman pada umur 36 bulan menunjukkan pertumbuhan baik dan berbeda sangat nyata dibanding perlakuan ukuran rumpang $113 \mathrm{~m}^{2}$ (rumpang ukuran $\emptyset=6 \mathrm{~m}$ ) dan kontrol. 
2. Disarankan pengembangan tanaman jenis Shorea pauciflora dalam skala luas sebaiknya dilakukan pada luas rumpang $254 \mathrm{~m}^{2}$ (rumpang ukuran diameter $9 \mathrm{~m}$ dan luas rumpang $452 \mathrm{~m}^{2}$ (rumpang ukuran diameter $12 \mathrm{~m}$ ), sebab tanaman tumbuh optimal dalam iklim mikro rumpang.

3. Perlu dilakukan penelitian lebih lanjut jenis meranti merah (Shorea pauciflora) khususnya dari aspek silvikulturnya diantaranya penelitian penanaman dengan menggunakan benih dari berbagai tempat asalnya (provenance trial) untuk mendapatkan materi benih yang cocok dan berkualitas di lokasi pengembangan jenis tersebut.

\section{DAFTAR PUSTAKA}

FAO. 2000. The Global Forest Resources Assesment 2000. Rome Italy. Summary Report.

Jafarsidik, M. Y. 1998. Regeneration of the Forets After Logging at Kintap, South Kalimantan, Indonesia. PhD Thesis, Department of Biological and Molecular Sciences, University of Strirling, Scotland.

Martawijaya, A., Kartasujana, I.; Kadir, K.; dan Prawira, S.A. 1989. Atlas Kayu Indonesia Jilid I. Departemen Kehutanan Badan Penelitian dan Pengembangan Kehutanan, Bogor-Indonesia.

Newman, M.F; Buegess, P.F. and Whitmore, T.C. 1999. Pedoman Identifikasi Pohon-pohon Dipterocarpaceae Pulau Kalimantan. Ratna Rosiana Budiman (Penerjemah). Hadi Sutarno, Rochadi Abdulhadi dan Ani Kartikari (Penyunting). Prosea Indonesia, Bogor.

Panjaitan, S., Jafarsidik, M. Y., dan Supriadi, H. 2004. Pembangunan Hutan Tanaman Meranti Dalam Rangka Menunjang GN-RHL di Kalimantan Selatan dan Kalimantan Tengah. Prosiding Seminar Ilmiah Hasil-Hasil Penelitian Balai Penelitian dan Pengembangan Hutan Tanaman Indonesia Bagian Timur. Departemen Kehutanan Badan Penelitian dan Pengembangan Kehutanan. Pusat Penelitian dan Pengembangan Bioteknologi dan Pemuliaan Tanaman Hutan, Yogyakarta. P. 139144.

Sagala, A.P.S.1989. Memanfaatkan dan Melestarikan Hutan Produksi Indonesia.Departemen Kehutanan Ditjen Reboisasi dan Rehabilitasi Lahan. Balai Teknologi Reboisasi Banjarbaru, Banjarbaru.

Sagala, A.P.S. 1994. Mengelola Lahan Kehutanan Indonesia. Yayasan Obor Indonesia, Jakarta.534 p. Setyati, S. H. 1984. Pengantar Agronomi. Penerbit Gramedia Utama, Jakarta. Cetakan ke 5. Sudjana. 1991. Desain dan Analisis Eksperimen (Edisi III). Penerbit Tarsito Bandung, Bandung.

Rahman, S. 1992. Studi Komposisi Vegetasi Hutan Tropis Sebelum dan Sesudah Penebangan Pada HPH PT Edi Mulya Corpotarion di Batu Kajang, Kalimantan Timur.

Whitmore, T.C. 1975. Tropical Rain Forest of The Far East, Clarendon Press, Oxford. 